University of Nebraska - Lincoln

DigitalCommons@University of Nebraska - Lincoln

Faculty Publications: Department of Teaching, Department of Teaching, Learning and Teacher Learning and Teacher Education

Education

September 2004

\title{
Retrieving possibilities: confronting a forgetfulness and deformation of teaching/learning methodology
}

Margaret A. Macintyre Latta

University of Nebraska-Lincoln, Margaret.Macintyre.Latta@ubc.ca

Follow this and additional works at: https://digitalcommons.unl.edu/teachlearnfacpub

Part of the Teacher Education and Professional Development Commons

Macintyre Latta, Margaret A., "Retrieving possibilities: confronting a forgetfulness and deformation of teaching/learning methodology" (2004). Faculty Publications: Department of Teaching, Learning and Teacher Education. 1.

https://digitalcommons.unl.edu/teachlearnfacpub/1

This Article is brought to you for free and open access by the Department of Teaching, Learning and Teacher Education at DigitalCommons@University of Nebraska - Lincoln. It has been accepted for inclusion in Faculty Publications: Department of Teaching, Learning and Teacher Education by an authorized administrator of DigitalCommons@University of Nebraska - Lincoln. 


\section{Retrieving possibilities: confronting a forgetfulness and deformation of teaching/learning methodology *}

\section{Margaret Macintyre Latta ${ }^{+}$}

University of Nebraska-Lincoln, USA

This paper draws on data collected in a one-year research project focusing on elucidating theory/practice relations in learning to teach. As a teacher educator I grapple with the nature and role of teaching methodology. The notion of method, with its implied order and certainty, is confronted alongside prospective teachers throughout their coursework and student-teaching experiences. Reflexivity is considered essential to this research process, providing a means to address the interface between the empirical data collected alongside student-teachers and its interpretations. In this regard I draw on the historical writings of Dewey $(1904,1910,1938)$ and Bakhtin (1990, 1993), found to provide insights into theory/practice relations. Through Dewey's thinking, bearings are retrieved that reorient teaching/learning methodology toward neglected needs and opportunities in learning to teach. Through Bakhtin's early aesthetic essays, a language is retrieved that addresses forgotten assumptions central to reformulating teaching methodology. This paper pursues the necessary character of a teacher preparation course fostering a mode of method that is radically different from the technical one. It is a mode of method that attends to the voices of prospective teachers in schools confronting the nature of learners and learning, teachers and teaching. It is a mode of method that reminds all involved in the schooling process of the power of teaching/learning restored to its participatory and complex nature.

* Published in Teachers \& Teaching: Theory and Practice, 10 (3), 329-344. ISSN 1354-0602 (print) / ISSN 1470-1278 (online)/04/030329-16 (C) 2004 Taylor \& Francis Ltd DOI: 10.1080/1354060042000204379. Used by permission.

${ }^{\dagger}$ University of Nebraska-Lincoln, College of Education and Human Sciences, 118 Henzlik Hall, Lincoln, NE 68588-0355, USA. Email: mlatta2@unl.edu

\section{Introduction}

As a new teacher educator I find myself negotiating coursework alongside prospective and professional teachers questioning underlying assumptions about teaching and learning, considering criteria and evidence of teaching success, and examining the consequences for learners and teachers. The commitment I act on is echoed in Cochran-Smith's (2001) plea to keep rich and complex understandings of teaching and learning at the center of teacher education. She insists teacher educators must 'take control of framing the outcomes of teacher education' rather than allowing outcomes to frame and undermine teaching and learning (Cochran-Smith, 2001, p. 40). Korthagen (2001) reiterates this plea, describing actions to take as a teacher educator. This paper documents my tentative explorations as a teacher educator to take up this plea, orienting teaching and learning beyond applied technical activity toward the act of teaching and learning itself, as it occurs in complex meeting spaces of the personal and relational, demanding constant discernment in concrete situations. This suggests to me that teaching/learning ought to be ambiguous, uncertain, and complex; difficulty is implicit.

I search for the necessary character of a teaching methods course embracing these assumptions of ambiguity and uncertainty in teaching and learning. It is an attempt to provide prospective teachers with an understanding of the existing complexity in classrooms, acknowledging that teaching/learning cannot be separated from the larger social, cultural, historical, and political contexts that frame schooling. It is an attempt to find opportunities for prospective teachers to experience both the necessity and difficulty of attending to this complexity. It is an attempt to articulate a mode of method that, through inhering in the difficulty, is radically different from the technical one.

Throughout this search reflexivity is considered essential to the research process, providing a means to address the interface between the empirical data collected and its interpretations. Alvesson and Sköldberg (2000) describe such reflexive interpretation involv- 
ing interaction between:

Interpretations of a hermeneutic kind, which in turn are subjected to critical scrutiny followed by rhetorical self-analysis and an attempt to tackle the problems of text and authority by opening up the text more clearly: drawing out ambiguities in ways of dealing with the subject matter, indicating limitations and arbitrariness in what is being represented. (p. 255)

The interface between the empirical data and these different interpretations is pursued through bringing the thinking of Dewey (1904, 1910, 1938) and Bakhtin (1990, 1993) alongside the personal experiences of student-teachers and myself as a teacher educator. The data included throughout the paper is representative of dominant themes resulting from a one-year research project alongside 20 students in teacher preparation methods courses and throughout student teaching experiences in two research sites focusing on the elucidation of theory/practice relationships in learning to teach. Data collection includes regular taped interviews, written responses to casework taken up in the methods course, and field journal entries by student teachers documenting their experiences, the researcher's observations of learning to teach out in schools and throughout the coursework, and the research literature situating the inquiry and the traditions inherited and being reconstructed. Reflexivity involves philosophical reflection alongside the problematization of learning to teach and, thus, ongoing interaction between theoretical frameworks and empirical findings.

\section{Tentative explorations}

As I meet the teaching methods class, I initially find prospective teachers hold on to preconceived assumptions tightly, correlating teaching/learning with mastery of the teacher's functionary role. For example, a student-teacher writes:

I wanted to learn the secrets of teaching. I honestly thought I could take a class that would impart this knowledge to me. That is why I was in class. However, that aspiration was shattered. I realized that no one was going to teach me how to teach; pedagogy could not be boiled down to a formula that could be applied across the board. Worse yet, my professor offered multiple ways to consider teaching and learning and the literature only offered more questions. Similar to Jamie Owl [a reference to the student-teacher Britzman (1991) writes about], I began to wonder: What am I doing here? Can I learn to become a good teacher? (Artifact \#5, 27 January 2000)

As a teacher educator, I reckon with the tremendous responsibility implicit in 'shattering' taken-for-granted teaching/learning assumptions. I ask myself, 'What is it I intend to offer to prospective teachers instead?' I know that I desire them to reformulate teaching/learning as a reciprocal creating, making encounter alongside students and others, attending to the particularities of individuals and contexts. I know I desire them to experience teaching/learning as a deliberate and responsible endeavor by individuals who know what they are doing, even though they do not know in advance what might come of it. I grapple with how I might create the necessary conditions for such formation.

In an effort to retrieve some of these conditions, I turn to my knowing of teaching and learning and find resonance in the writings of Dewey $(1904,1910,1938)$ and Bakhtin (1990, 1993). I find these historical writings 'provide sources of ideas for the present and yield treasures to those who search for them with new thoughts and saving acts of remembrance' (d'Entreves, 1994, p. 5). First, in Dewey's 1904 thinking 100 years ago, I retrieve bearings (p. 17) that reorient the notion of method, changing the conception of what constitutes teaching/learning experience. These bearings point to neglected needs and opportunities (p. 13) in learning to teach. Second, in Bakhtin's early aesthetic essays I retrieve a language that voices forgotten assumptions central to reformulating teaching methodology. Through reflexive writing (Alvesson \& Sköldberg, 2000) I interact with these retrieved ideas as I encounter them in my own teaching experience, the research literature, my role as a teacher educator, and data generated through participant/observation of student-teachers. 


\section{Dewey's bearings}

Dewey (1904) describes how teachers and prospective teachers flock to receive prepackaged learning materials and ready-made lessons, answering how to teach this or that (p. 16). He abhors such an impoverished understanding of method and asks, 'What must be the aim and spirit of theory in order that practice work may really serve the purpose of an educational laboratory?' (Dewey, 1904, p. 16). Dewey interrogates why theory is considered to be abstruse and remote (1904, p. 16) unless prospective teachers are immersed in the work of teaching immediately. He builds a case arguing that such immediacy in student-teaching is what makes theory abstruse and remote, focusing experiences solely on realizing visible capability evidenced in routines, orderliness, and conforming, receptive students. I am confronted by Dewey's warning. Already I see prospective teachers lured by assumptions of teaching as mastery of techniques and the teacher's role as functionary and controlling. Their seduction lies in the ease established and sustained by negating the presence of any difficulty. But, to relay teaching and learning in these ways is a misrepresentation of what I know teaching and learning to actually be.

Dewey (1904) puts forth bearings integral to theory that reorients the nature of method (p. 17). To do so he distinguishes between 'laboratory' and 'apprentice' practice work:

If the primary object of practice is acquiring skill in performing the duties of a teacher, then the amount of time given to practice work, the place at which it is introduced, the method of conducting it, of supervising, criticizing, and correlating it, will differ widely from the method where the laboratory ideal prevails; and vice versa. (Dewey, 1904, p. 10)

He argues that apprenticeship orients practice work toward securing outward proficiency in teachers' practices, fixing a studentteacher's attention in a wrong direction (Dewey, 1904, p. 13). The bearings student-teachers are positioned to orient their teaching/learning practices toward are limited solely to needs and op- portunities arising out of lesson management concerns. As Dewey comments, 'Such persons seem to know how to teach, but they are not students of teaching' (1904, p. 15). A much wider set of needs and opportunities arises if student-teachers are positioned to take up the teacher's role as catalyst for the movement of thought in their students in a laboratory-like context, allowing and encouraging student-teachers to experiment with many ways to assume the role of teacher. To flesh this out Dewey further distinguishes between 'inner' and 'external' attention (1904, pp. 13, 14). Inner attention is manifested through relationships found between students, teacher, and subject matter. A teacher searches for ways to draw students into the depth and complexity of subject matter via these relationships. External attention is manifested 'in certain conventional postures and physical attitudes rather than in the movement of thought' (p. 14). Dewey describes how student-teachers placed prematurely into the role of teacher focus on external rather than inner concerns. Thus, student-teachers acquire an outward form of method, neglecting or dismissing the interplay of students' thoughts, images, and emotions. Dewey's concern is that studentteachers acquiring practice oriented only to external bearings rarely gain access to the potential of transcending external bearings toward internal bearings in teaching/learning situations.

Dewey's (1904) internal bearings orient attention accordingly:

- Teaching/learning is personal and situational.

- Teaching/learning entails building relationships between self, others, and subject matter.

- Teaching/learning acknowledges and is sensitive to children's realities and experiences.

- Teaching/learning is alert and thoughtful.

- Teaching/learning is based on an ethic of caring.

- Teaching/learning is about creating knowledge that is meaningful for participants.

- Teaching/learning is constant practical activity in concrete situations and relations. 
Thus, a technical how-to-manual cannot be written about teaching. Rather, it is a mode of being. Dewey's internal bearings conceive of teaching/learning as a personal encounter between self and others. These ways of being with others and otherness are interrelated and connected to each other, leading to the following lived consequences for teaching and learning:

- Teaching involves seeing and acting grounded in one another. Acting accordingly is thus implicit in seeing the concrete situation as it is. Teachers must employ tacit knowings of process and content as they dwell in and live through learning situations. Thus, theory informs practice and practice informs theory. The ongoing mutual responsiveness between self as knower and situation is crucial to this growth.

- Curriculum is likened to a situated event-an event to which all contextual elements contribute.

- Knowing as conceptualized is a process of inquiry residing in self-experience. It is a process of creating meaning through engagement in the sense making process.

- A co-presence develops in such a teaching/learning milieu. Purpose for learning becomes a cooperative enterprise between teacher and learner. 'The essential point is that the purpose grow and take shape through the process of social intelligence' (Dewey, 1938, p. 85). Connectedness is the necessary thread that precludes meaningful learning.

- If teaching demands such involvement and interpretation, it follows that the presence of subjectivity has to be addressed. Objectivity in the positivistic sense of the word has no place here. However, if we think of objective as being a periodic distancing from the closeness of situation, it is necessary. The interactions of the objective and subjective dialectically reinforce each other.

Dewey's internal bearings conceptualize teaching/learning as a complex interplay between these interactive relationships of see- ing/acting, student/teacher, theory/ practice, and subjectivity/objectivity. In order for student-teachers to gain access to these interactive relationships in action, Dewey is adamant about:

- The important role and place of guided observation in student-teaching experiences.

- The cultivation of an intimate understanding of the lives of children and the work entailed in teaching/learning.

- Sufficient time to assimilate multiple teaching/learning perspectives.

- Liberty to experiment with these perspectives and act on insights.

- Ongoing critical discussion aimed at increased thoughtfulness regarding teaching practices. (Dewey, 1904, pp. 26-30).

\section{Bakhtin's language}

Dewey's (1904) perspectives are grounded in the act of teaching, always operating in the immediacy of a given situation. Bakhtin (1990) reiterates this, emphasizing the uniqueness and singularity of such acts or events for each person. From within the act or deed, participatory thinking orients individuals (Bakhtin, 1990, p. 30). This focus on the act as it is happening makes it necessary to see the act not as a given contemplated at a distance, but to see from within, a taking into account of the givenness, moment by moment. 'And all these moments, which make up the event in its totality, are present to him [sic]as something given and as something to be achieved' conjointly (Bakhtin, 1990, p. 30). The simultaneous awareness of both something given and something yet to be achieved is crucial to the intent of Bakhtin's attempt to describe the world in which the act/actor becomes aware of itself/himself/herself; a catching of self in the act. Bakhtin is clear that it is not aimed at describing the world produced by that act (1990, p. 31). I find a strong affinity here with Dewey's (1904) conviction that the act of teaching dwells primarily in knowledge as concrete and particular. But, it is through Bakhtin's thinking that I realize that the concrete is not simply a 
step toward something else, but rather, concomitantly, a knowing of the present and how to meaningfully proceed. Acting accordingly is implicit in seeing the concrete situation as it is - and as it might be, to see possibilities for meaningful learning encounters. Bakhtin's insistence on attending to the act of creating within the act of creating and not the creation itself parallels Dewey's distinction between internal/external attention.

Both Bakhtin (1990) and Dewey (1904) are concerned with the movement of thought. Bakhtin suggests a useful language for describing such participatory thinking that I see as integral to the search for Dewey's necessary spirit of theory. Bakhtin portrays this movement of thought as the problem of content, material, and form, encountered by the creator (1990, pp. 274-318). Thus, being positioned to enter into thinking as a creator demands grappling with the problem of content, material, and form. Content, material, and form are interrelated and cannot be understood apart from each other. Bakhtin conceives of content to be what work is about, matter as the concrete and abstract materials out of which work is constructed, and form as the relationships in work between self, content, and material. His notion of answerability arises out of interaction between content, material, and form. Experiencing this interdependence is derived from a fundamental reciprocity between self, content, material, and form. Bakhtin explains how this is not derived from a mechanical relationship of parts to whole:

The parts of such a whole are contiguous and touch each other,

but in themselves they remain alien to each other. $(1990$, p. 1)

Rather, answerability is not a given, but is seen as a task to engage in and with, through participation engaging self and other. Answerability demands involvement taking 'an axiological stand in every moment of one's life or to position oneself with respect to values' (Bakhtin, 1990, pp. 87-88). Bakhtin (1986) explains how his notion of outsideness makes this possible. Outsideness speaks to his interpretation of the self as a fully embodied self, a self that is constituted interdependently with the other. This interdependence is realized at boundaries where one comes up against or comes to meet another. Each needs the other. A self-consciousness takes hold that is not grounded in a solitary consciousness, but rather a developing greater consciousness of other, others, and in turn, self. Thus, neither self nor other are bound entities; they intermingle in a bodyworld relationship yielding an outside-ness, belonging as much to the other as self. Change and transformation are always possible through recognizing the interdependency and fluidity between self and other. A tentative wholeness is forged. Such interaction of self and other is ongoing and ultimately unfinizable. Unfinizability is Bakhtin's notion of unrealized potential.

Bakhtin's (1990, 1993) notions of answerability, outsideness, and unfinalizability form a space for learning that positions participants in-between content, material, and form. The underlying aim is that of the self wholly involved. A curious exchange unfolds between self and other as creators and re-creators of meanings. I use curious to acknowledge the embodied particularities of such exchanges that cannot reoccur. The creating/responding encounter entered into by participants through answerability, outsideness, and unfinalizability embraces Dewey's interplay of interactive relationships between seeing/acting, student/teacher, theory/practice, and subjective/objective. Momentary semblances of meaning come to be; the unity is dynamic; parts are always evolving and unfolding into a whole. As such, teaching/learning situations possessed of answerability, outsideness, and unfinalizability are always spaces in the making, striving for possibilities. And, as Bakhtin (1993) claims, it is a learning space only for 'those who wish and know how to think participatively' (p. 19), living their learning through answerability, outsideness, and unfinalizability.

\section{Retrieving possibilities}

Through bringing Dewey's (1904) internal bearings alongside Bakhtin's $(1990,1993)$ language for describing involvement in process, I retrieve the following possibilities for learning to teach: 
- Relationships between students, teacher, and subject matter are the materials of method. The raw materials live in the experiences of students, teacher, and the subject matter itself. Recognizing these raw materials and finding ways to build relationships through answerability, outsideness, and unfinalizability, connecting students, teacher, and subject matter, is the work of teaching/learning.

- As these relationships between students and subject matter emerge and develop the teacher's capacity to orient practices toward internal attention, responding sensitively, fostering connections derived from an intimate understanding of students and situation, is required. Deliberation of these relationships is the indispensable condition of thinking methodologically.

- Method as coming into being is a manifesting, evoking, transforming movement. Method then is not applied or imposed, but rather is a knowing in action that can never be fully anticipated.

As I take up the challenge of working alongside student-teachers negotiating learning to teach, I attempt to orient toward these possibilities.

I develop case-work for my student-teachers to address (extending over 12 weeks) that confronts issues recursively regarding the nature of learners and learning, the nature of teachers and teaching, the nature of subject matter, and the nature of lesson design and facilitation. Each case introduces a text (a narrative, dialog, film, debate, scenario) inviting students to question taken-for-granted learning assumptions. Initial responses are explored and then further pursued through the research literature. Student-teachers are asked to recall personal teaching/learning experiences and, as they increasingly spend time in classrooms, these concrete realities figure prominently into casework. Thus, prospective teachers begin to articulate a personal philosophy for teaching and learning. I understand these to be tentative but necessary beginnings. I deliberately attempt to position student-teachers to be answerable moment by moment and thus experience first-hand the nature of answerability as being dependent on personal involvement. For example, a student-teacher practicing teaching in a high school art class begins to address answerability in his teaching practices and confronts the reciprocal effect, repositioning students to be answerable too. His journal states:

When students ask me what I think of their work, my first instinct is to say, 'That's great, it looks good'. Hey, they are at least producing work and art is so subjective. I do not feel like I am all knowing and I especially do not want to turn them off. But, on the other hand, increasingly, I feel my response is so inadequate. I am compelled to use my trained eye, to help them develop their sense of art, to challenge them. After all, my job is to develop artistic thinking. (Artifact no. 40, 2 November 2000)

As such, a fundamental reciprocity is initiated between this prospective teacher and his learning. Bakhtin (1990) explains that he sees this living and moving 'not in a vacuum; but in an intense axiological atmosphere of responsible, answerable, indetermination' (p. 275). So, answerability positions participants within an in-between space, attentive to the movement of thought. It is the in-between space I want prospective teachers to discover, constituted in relationships between students, teacher, and subject matter, as the materials of method. Perhaps through giving serious consideration to questioning tactfully in teaching and learning, this prospective teacher will experience the potential and find ways to connect students to their work and thinking, gaining momentum or direction to pursue further thinking. Another student-teacher writes: 'I am increasingly aware of my identity as I wonder how I fit into the shoes of a teacher' (Artifact \#71, 15 January 2000). Perhaps through giving serious consideration to issues in teaching and learning, prospective teachers confront how these issues relate to personal values and beliefs and how they might surface in their teaching. I note that most of my students' response journals indicate beginnings of this felt interdependence as the indispensable condition of thinking methodologically. Seemingly, student-teachers experience such in- 
terdependence in moments of participating in it. A student-teacher writes about being in schools, commenting that:

When I stepped into the classroom, I would interact with students. In the process, I would step outside myself as best I could and observe who I was while interacting. Did my perceptions of self fit with how others saw me? Was I reaching the child? Was he/she reaching back to me? Was our interaction around subject matter meaningful? (Artifact no. 12, 13 February 2000)

I am ecstatic about these questions for, as the student-teacher further comments, 'It reinforces the humility with which I must approach this awesome thing called teaching' (Artifact \# 12, 13 February 2000). It also tells me that Bakhtin's notion of outsideness is taking on a lived meaning. The student-teacher is confronting his taken-for-granted assumptions about teaching and learning, questioning his values and beliefs that he takes to his practices. This student-teacher goes on to clarify that, in meeting Bakhtin's notion of outsideness, he was also re-positioning students to confront outsideness too. His journal states:

When a student asks you a question, there is that tug. 'Gee, why don't I know? I should know that'. My gut response was not to admit that I did not know something. I was afraid of losing face with the kids. And, I did this to begin with. I was trying to live up to the image of a teacher as the all-knowing, all seeing, omnipotent person. But, I found myself resorting to being teacher as drill sergeant, which I despise. In a sense I had control, although I didn't really. Defensive teaching describes what my experience felt like. And so, I made an effort to resist the tug to pretend to know everything and instead looked for opportunities to admit I didn't know and get students searching for answers with my support and assistance. This was easier said than done. One on one I experienced some success but with a large group I am still playing with practical ways to allow for learning to take multiple directions. It is messy, but the messiness feels better than the pretense of order. (Artifact no. 39, 28 March 2001)

This prospective teacher also knows he ought to address these questions over and over again in his practices as a teacher. Such a realization is the intent of Bakhtin's notion of unfinalizability. A tentative wholeness is forged out of the student-teacher's explorations of teaching practice. But an open-endedness always remains to unasked for and unanticipated learnings, mistakes, intuitive responses, experimentation and, ultimately, the understanding of sense always in the making - for himself and for students. Teaching and learning is experienced as a 'moving force' (Dewey, 1938, p. 38).

So, intentionally answerability, outsideness, and unfinalizability permeate the casework. Their interplay involves student-teachers in participatory thinking in which I begin to see evidence of relationships being pursued between self and subject matter, greater sensitivity to the potential of these found relationships as discoveries that guide learning, and a willingness to embark into the unknown. There is a found commitment and vitality that is compelling. I talk with students about these observations of their processes of becoming teachers to heighten awareness of the deliberate interplay between answerability, outsideness and unfinalizability. A studentteacher's written response gives me hope that my aim is being realized:

You have asked us to think deeply and it has been difficult work. There is so much to consider in teaching and learning that I was oblivious to. But, I am more committed than ever to take this passion I feel to my classroom and students one day. I want to instill in students a genuine desire for learning. I have liked how it has made me feel. (Artifact no. 15, 10 February 2000)

Acting as a catalyst to answerability, outsideness, and unfinalizability, layered within the course, I have prospective teachers observing in classrooms looking for visible and invisible differences through attending to individual students, comparing physical environments, contexts for learning, and teaching/learning ap- 
proaches. The ensuing large group discussion is fostered through critical analysis of 'trial' peer teaching/learning encounters and videos portraying teaching/learning encounters. Prospective teachers indicate that Dewey's (1904) aim of alert and watchful teaching is a worthwhile pursuit. Some written comments are as follows:

The observation was incredibly necessary. I sat and wrote, but I also wandered and talked to the kids. When I started actually teaching in the second term, I knew a lot of these kids; their strengths and weaknesses. (Artifact no. 20, 15 February 2000)

In some of the classrooms that I visited over the past few weeks, I felt what I have called a good or pleasant classroom atmosphere, and classroom atmospheres that I determined were neither good nor pleasant. In defining a good classroom atmosphere, I used phrases such as: conducive to learning, mutual respect between students and teacher, good inter-student relationships, highly attentive or focused students, and good working atmosphere. These phrases are all very subjective, however in cases where I sensed a good atmosphere, it was one in which I felt that if I were a student, I would be able to (and feel comfortable) pay attention to what is going on in the class, ask questions and get my work done. As a soon to become teacher, I feel understanding more about what makes a good classroom atmosphere, and what role the teacher plays in this is of paramount importance in being able to serve my students. (Artifact \#23, 22 February 2000)

The observations were where I became unsettled with what was happening. On the surface the classroom was extremely well managed, orderly, bright, colorful; a real showplace. But, the longer I spent in the classroom I saw very little room for kids to bring their questions and experiences. It was a very tightly orchestrated and the kids were just placeholders. (Artifact no. 17, 10 February 2000)

Being alert and watchful promotes thoughtful consideration/reconsideration and is sometimes disturbing. But, I assert that being invested in becoming a teacher demands such thoughtfulness and ongoing questioning. As the casework comes to an end, I am satisfied that prospective teachers have developed some awareness of the tremendous difficulty and complexity implicit in teaching. For example, a student-teacher comments:

If there is one thing I learned over the past few weeks, it is that a teacher must know their subject matter inside and out. To be able to create meaning and spark ideas in students a teacher must be able to twist the curriculum into many different shapes. They must be willing to try new ways of approaching subject matter. This means PREPARE, PREPARE, PREPARE! I cannot emphasize that word enough. (Artifact no. 25, 25 February 2000)

At the time I think such overwhelming feelings regarding the magnitude of the act of teaching and learning are healthy at this stage. But, as students move to spending most of their time in studentteaching practicums, I increasingly call the wisdom of this thinking into question. I wonder whether I have set them up to be unsuccessful as student-teachers. The forming of fragile understandings around ways to negotiate teaching and learning are put aside, consumed by negotiating a well-managed classroom. As I visit classrooms, I am disappointed to see all student-teachers have seemingly forgotten about pursuing fleshed out lesson beginnings toward drawing students into the depth and complexity of subject matter. I am particularly disturbed by this as together we spent two weeks examining and playing with ways to enter into subject matter with students. Fueled by this disturbance, I spend significant time alongside student-teachers in classrooms, attempting to foster greater attunement within teaching/learning encounters. For some studentteachers, prompting them to recall these considerations causes them to recognize their absence and begin to deliberately create teaching/learning encounters that foster their presence. An example of a common response was:

It is not that I did not give some thought to how I might get students really involved, but I find myself panicking as I face 30 faces. It is just easier to get everyone busy and then work one on one with students. (Artifact no. 31, 8 March 2000)

In classrooms in which partner teachers support this kind of explo- 
ration, student-teachers are given liberty to play with many ways to be a teacher, their understandings maturing and deepening. The following excerpts from field journals reflect such growth. One student-teacher writes:

At the heart of my motivation is the value I see in children. Their lives are thrust into the classroom. I want their vulnerability before me to be mirrored in my vulnerability, my integrity as a caring teacher. I desire that they know, without doubt, that I consider them as possessing true value both in their being and in their knowing. I desire to communicate this in my day-to-day interactions, verbally and subtly ... Being an effective teacher begins with the ability to be fully present in the moment. You see it in the teacher's eye contact, her non-verbal, and her attentiveness. She realizes that she is in a child's world, not an adults'. She is focused, well prepared, and willing to be flexible in honoring students' ideas. She does not necessarily follow the lesson plan rigidly, but allows for other roads into the subject matter. (Artifact no. 34, 10 March 2000)

Another student-teacher writes:

Entering into a child's world of learning is intentional. There is an intentional space for the child to enter. Subject matter also takes it place by entering in a confident manner, for it holds us accountable. Questions and ongoing conversations fill the space as the participants interact in a dynamic fashion, never twice the same. The teacher establishes safe guidelines built on trust. She is aware of the context and thoughtfully considers the implications. The inviting to enter is gentle, yet reassuring, for she knows how and when to enter and when to allow the space-when to sit silently waiting ... The student-teacher relationship is unique. It requires the great understanding of being fully present in the moment, yet seeing the bigger picture. What aspects of self and subject material do I pay attention to? How do I develop relationship when the tyranny of classroom urgency propels me in many directions? What is it that warrants my time and focus? How do I keep the students in focus when considering the demands of curriculum? The basis of pedagogical relationship is built within a willingness to enter with integrity, honesty, re- spect, and humility. This is an intensely moral process requiring much reflection. (Artifact no. 37, 13 March 2000)

Both student-teachers develop an attentiveness within their teaching/learning practices that has them continuously questioning practices, thus demanding discernment and care toward building relationships between students and subject matter.

One partner teacher comments on the ways this had caused her to reconsider her own teaching/learning practices:

This student teacher was very different from any I had ever had in my classroom. She was not at all concerned about compiling a portfolio for a job. She totally engaged with finding ways to interact students with subject matter. I watched her wrestle with circumstances, take pleasure in moments that worked, and marveled at the commitment. It re-awakened some of that in me. (Artifact no. 38, 21 March 2000)

But, the more common story is one of no time, no inclination, and no disruption of things as they are in classrooms. Student-teachers in these classrooms are quickly immersed in a flurry of activity, a pace that demands they follow the lead and assume the lead as fast as possible. I have not prepared prospective teachers for such negotiation at all. In some cases student-teachers choose to operate in survival mode and muster the necessary façade. One studentteacher comments:

How do you think about the direction of your lessons if the teacher is not willing to let go? My partner teacher told me specifically what to teach and exactly how to teach it. She even gave instructions for the order of presentation. And, I tried to add some of my own creativity, but it was not worth it. The feedback always reflected whether or not I had followed her plan. (Artifact no. 30, 2 March 2000)

My visits to classrooms like the one already described are difficult. Student-teachers know I do not like what I am seeing but they do not feel they have a choice. Our conversations try to focus on what might be missing and the relative importance of these missing 
aspects. A student-teacher explains:

There is tons of potential in the classroom. The teacher is really highly skilled. The materials available are plentiful and varied. Lacking is much interaction. But, I see that a tremendous amount of effort goes into her lessons. The way I would do it would be different. My classroom is going to look and feel different. I respect my partner teacher and am drawing from the experience toward a style of my own. (Artifact no. 32, 30 March 2000)

Partner teachers' comments to me reinforce the student-teachers' concerns for mastering managerial teaching, reflected in telling statements such as 'Timing needs work', 'Board notes need to be more readable', 'An overhead projector needs to be utilized', 'Student instructions need to be spelled out'. The supreme sign of mastering teaching seemed to equate with 'the length of time a student teacher was left on their own and all hell did not break loose'. While not dismissing the importance of any one of these comments, to choose them as indicators of meaningful teaching/learning encounters frightens me. And, as much as this frightens me, fear of loss of classroom management is a primary concern of these teachers. A student-teacher reiterates this saying:

My partner teacher told me right up front after a few days of being in the classroom that behavior management was her number one thing. I recall the strength of her words, 'If you do not have behavior management you do not have anything.' So, I understood that control was first, and then learning. And I did not want the classroom to be totally out of control. I knew I had a mandate to teach and I knew I was being watched. The fear was in me. (Artifact no. 16, 17 February 2000)

The fearfulness around loss of control permeated teaching and learning, occluding any hope of play between answerability, outsideness, and unfinalizability. Yet, I believe it is play between answerability, outsideness, and unfinalizability that is the spirit of theory that Dewey (1904) sought. For, it is through play between these entities that some student-teachers began to see and experi- ence teaching and learning as reciprocal interaction and modification between self and other. It is through such play that studentteachers began to attend to their findings for further inquiry. Most importantly, they began to experience that such teaching method is not arbitrary, but derived from attunement to the particularities of teaching/learning encounters. The playful spirit evokes a tentative trust in process. Student-teachers began to recognize answerability, outsideness, and unfinalizability in their own thinking; in their own play with becoming a teacher. But these tentative, uncertain explorations are more apt to be frozen than fostered in their practicum experiences in schools. Most student-teachers do not continue to see or recognize answerability, outsideness, or unfinalizability in teaching/learning situations. Dewey (1904) claims that such interplay is a fundamental condition of mental growth: 'To be able to keep track of this mental play, to recognize the signs of its presence or absence, and to test apparent results by it, is the supreme mark and criteria of a teacher' (p. 14). Clearly, there are not enough opportunities to play with 'mind activity' in classrooms. A student-teacher comments:

If I had seen something different, not lecturing, but different processes for learning and assessment, that would have helped. I wanted to be different but had no idea how to be otherwise in this classroom. I needed to be able to see teachers working in various ways with their students and be able to ask them, 'What is going on in their minds?' and 'Why are they doing what they are doing?' (Artifact no. 29, 7 March 2000)

The classrooms are not yielding many ideas of ways to promote 'mind activity', thus stunting the critical ongoing conversations. And, so, most student-teachers hold on to teaching/learning principles as abstract ideals taking little heed of them in the concrete realities of classroom life, confirming Dewey's 1904 declaration that 'theory and practice do not grow out of and into the teacher's personal experience' (p. 15). 


\section{A methodological distinction}

A methodological distinction surfaces as Csordis (1994) points out between representation and being-in-the-world. It is this methodological distinction that prospective teachers meet in classrooms. For, it is in the concrete realities of classroom life that teaching/learning is experienced as a functionary role or as a process emerging out of the act itself. There is little room for exploring teaching as being in the world where rigid rules dictate the way in which teaching/learning should be represented. Limitations unduly impinge upon or restrict the possibilities for interpreting teaching/learning encounters. Knowledge, taken up as representation, is imposed on students. Knowledge as being in the world comes not from learning about but from trying to do, from playing with possibilities searching for relationships between students, teacher, and subject matter. The development of such knowing in action allows for the discovery of potential. It permits possibilities to be included as the search evolves. Without a playful spirit it would seem that imaginative thought, requiring speculation and conjecturing about possibilities, might not be possible. So as these student-teachers find themselves in classrooms caught up in the immediacy of given situations, they are confronted with either contriving teaching/learning encounters to fit a fixed idea or acting on an openness to new ideas and an acceptance of alternatives through listening and responding to students and the particularities of contexts. Belief in the worthiness of the latter approach to teaching and learning translates into greater commitment to search for these considerations in their teaching/learning practices. When student-teachers demonstrate faith in process they focused on the encounter, attending closely to the particularities of students and context. It is through attending fully to this search that student-teachers find greater attunement to teaching/learning processes. An embodied know-how evolves that cannot be separated into distinct components such as pacing, voice undulations, monitoring student work habits, and so on. Rather, a 'mindful embodiment' (Field \& Macintyre Latta, 2001) emerges that is concomitantly aware of circumstances and the potential of those circumstances for learning.

Fostering faith or belief in process became my role as a teacher educator. The deliberate structure of the casework required entry into such a discourse. A confidence in working this way began to take hold, building a repertoire of teaching/ learning approaches and a boldness to rework and reformulate these approaches to fit new situations. But, the voices of many student-teachers do not indicate this unfolding sense of teaching and learning to be the norm in classrooms. The pleasure and self-investment student-teachers feel belong in teaching/learning encounters are not visible in classrooms. The choices student-teachers are asked to make in teaching/learning encounters are often insensitive to the needs of the environment, obscuring the nature of these decisions. Some studentteachers let go entirely of this thinking and take up teaching and learning as an applied act separated from self. Some are frustrated and saddened by the loss of self (in themselves and students) within the act of teaching, and grappled with why. And some find teaching moments that reconnect them (at least temporarily) to the importance of the act of participating in teaching and learning. I am struck by how deformed teaching and learning seems in contrast to what I attempted to instill within student-teachers. Dewey's (1904) needs and opportunities in learning to teach are forgotten, for the most part. His need for the self to be actively involved in sense making is limited. Opportunities to foster connections between students, subject matter, and teacher are rare experiences. Thus, deliberation of these relationships is restricted, more apt to be imaginative, and not tried out in practice. The playful spirit between answerability, outsideness, and unfinalizability lacks space and time to take many shapes in teaching/learning situations. Transformational experiences derived from such interplay seem crucial to understanding method as a movement evolving out of the specific teaching/learning circumstances. The few students that do find these opportunities develop a strong conviction for working in this way with students. I hope that this strength of conviction carries forward into their practices as classroom teachers. 
The complexity that Cochran Smith (2001) insists is essential to teacher education seems optimally experienced in spaces that provide opportunities for teachers and students to negotiate the acts of teaching and learning through adapting, building, and creating meaning. Korthagen's (2001) insistence on linking theory and practice in learning to teach seems only possible if the linkage is experienced as a co-presence, interdependent and fluid. What is clear to me is that if indeed the space for such co-presence can be realized, the power of the classroom experience for student-teachers cannot be understated. The student-teaching experience is where greater opportunities need to be created to play concretely with notions of teaching and learning yielded from multiple perspectives. Conversations critically examining teaching/learning practices need to be skillfully fostered on an ongoing basis. I must establish healthy working relationships with partner teachers who will work alongside the university with student-teachers. It is imperative that a shared understanding of the intents of practicum experiences for student-teachers be taken up collectively by all involved. The 'felt difficulty' (Dewey, 1910, p. 72) evoked is integral to inquiry of all kinds. The process becomes a search for intentionality that articulates a different mode of methodology worth paying attention to; one that is reflexive, an interchange of interpretations asking all involved to continually revise and enlarge understandings. This manifesting character assumes a mode of method understood as coming into being, reliant on the relational complexities coming together in particular teaching/learning situations and the ongoing contemplation of these relations. Dewey (1904) emphasizes that this movement 'must be known before it can be directed' (p. 21). And, thus, the task for me as a teacher educator must be to provide meaning-making spaces for prospective teachers to see and experience this movement of thinking in themselves and alongside their students. Through my search for such opportunities I find evidence that prospective teachers were indeed awakened to some of the power and potential for learners and learning, and feel hopeful that this will be further pursued in their future teaching practices. Such is the nature of reflexivity, experienced as a 'kind of mental activity which characterizes mental growth and, hence, the educative process' (Dewey, 1904, p.22). A spirit of inquiry emerges to which all must attend and take up. As a teacher educator I respond accordingly, seeing my work with prospective teachers as it is, and as it might be.

I do not want to forget teaching and learning's participatory nature. I do not want to deform the teaching act to an applied formula. All involved in the schooling process need to be re-acquainted with the power of the act of teaching from within the act itself. For out of the act of retrieving possibilities, I find hope that teaching and learning can be restored to its active and difficult nature. This is not nostalgic desire on my part, but a forgetfulness and deformation that I fear must be acted on to avoid potential disaster for learners and learning.

\section{Acknowledgements}

The Research Council, University of Nebraska-Lincoln, provided funding support for this research project over the 2002-2003 academic years. The author would also like to thank Dr Karl Hostetler, University of Nebraska-Lincoln, for his thoughtful comments on an early draft.

\section{Notes on contributor}

Margaret Macintyre Latta is currently an Assistant Professor at the University of Nebraska-Lincoln. She completed her Ph.D. at the University of Calgary, Alberta, Canada in 2000. Publications include The possibilities of play in the classroom: on the power of aesthetic experience in teaching, learning, and researching (2001, New York, Peter Lang) and Seeking Fragility's Presence, Philosophy of Education Yearbook (2002, Urbana, IL, University of Illinois). 


\section{References}

Alvesson, M. \& Sköldberg, K. (2000) Reflexive methodology (London, Sage).

Bakhtin, M. M. (1986) Speech genres and other late essays (Austin, TX, University of Texas Press).

Bakhtin, M. M. (1990) Art and answerability (Austin, TX, University of Texas Press).

Bakhtin, M. M. (1993) Toward a philosophy of the act (Austin, TX, University of Texas Press).

Britzman, D. (1991) Practice makes practice (New York, State University of New York Press).

Cochran-Smith, M. (2001) Constructing outcomes in teacher education: policy, practice and pitfalls, Education Policy Analysis Archives, 9(11), 157.

Csordis, T. J. (1994) Embodiment and experience (Cambridge, Cambridge University Press).

d'Entreves, M. P. (1994) The political philosophy of Hannah Arendt (London, Routledge).

Dewey, J. (1904) The relation of theory and practice in education, in: C. A. McMurry (Ed.) The relation of theory to practice in the education of teachers: the third yearbook of the National Society for the Scientific Study of Education (Chicago, IL, University of Chicago Press), 9-30.

Dewey, J. (1910) How we think (Boston, MA, Heath).

Dewey, J. (1938) Experience and education (New York, Collier Books). Field, J. C. \& Macintyre Latta, M. (2001) What counts as experience in teacher education?, Teaching and Teacher Education, An International Journal of Research and Studies, 17, 885-895.

Korthagen, F. A. J. (2001) Linking practice and theory (London, Lawrence Erlbaum Associates). 